\title{
POTENSI SIMPANAN KARBON PADA TEGAKAN REVEGETASI LAHAN PASCA TAMBANG PT HOLCIM INDONESIA TBK
}

\author{
Potential Carbon Stock on Revegetation Land Mine Closure Stand PT Holcim Indonesia Tbk
}

\author{
Omo Rusdiana ${ }^{*}$ dan Syidik Fahmi ${ }^{2}$
}

(Diterima Desember 2019/Disetujui Juli 2020)

\begin{abstract}
Global warming is a gradual increase in the average temperature of the Earth's atmosphere caused by the increased volumes of greenhouse gases such as carbon dioxide, methane, and nitrous oxide. Greenhouse gases is trapped inside the atmosphere and caused UV radiation difficulty passing through Earth's atmosphere, a processed is often referred to as the greenhouse effect. Reclamation and revegetation activities were expected could decrease the greenhouse effect. The aims of the research is to estimate total carbon stock in Pine Forest age 2005 or 11 years and 2012 or 4 years, and also to compare the result with former research in post mining revegetation site PT Holcim Indonesia Tbk. Biomass measurement of trees, poles, and saplings is conducted with non-destructive methods meanwhile biomass measurements of understorey, litter, and necromassa used destructive methods. The result showed that the value of biomass and carbon stock on the 2005 pine stand is acquired 75.31 tons/ha and 35.39 tons/ha. The value of the biomass and carbon stock on the 2012 pine stand is acquired 12.72 tons/ha and 5.98 ton/ha or increased from the previous year's measurement. Increasing of biomass content and carbon stocks is caused several factors such as increasing of diameter increment dan site quality.
\end{abstract}

Keywords: biomass, carbon, reclamation

\section{PENDAHULUAN}

Pemanasan Global atau Global Warming merupakan salah satu isu lingkungan penting, yang saat ini menjadi perhatian berbagai pihak diseluruh belahan dunia. Pemanasan global adalah meningkatnya temperatur ratarata suhu bumi yang diakibatkan oleh peningkatan konsentrasi Gas Rumah Kaca (GRK) seperti Karbon dioksida, Metana, dan Nitrogen oksida. Gas tersebut terakumulasi pada lapisan bawah atmosfer, sehingga menyebabkan tertahannya pantulan cahaya dari bumi atau biasa disebut efek rumah kaca. Berdasarkan fenomena tersebut apabila hal ini tidak ditangani dengan tepat maka akan membahayakan kehidupan manusia. Upaya yang dapat dilakukan untuk mengurangi dampak dari fenomena tersebut maka dibutuhkan suatu alat yang mampu mengurangi jumlah karbon di udara untuk menurunkan kembali suhu bumi. Penanaman pohon adalah salah satu cara efektif dalam mengurangi jumlah karbon karena, $\mathrm{CO}_{2}$ dibutuhkan oleh tanaman dalam proses fotosintesis yang kemudian dirubah tamanan dalam bentuk biomassa.

Menurut IPCC 1995 dalam Siregar 2007, proses degradasi hutan yang berkembang saat ini dapat meningkatkan emisi karbondioksida (CO2) di atmosfer

\footnotetext{
${ }^{1}$ Staf Pengajar Departemen Silvikultur, Fakultas Kehutanan dan Lingkungan Institut Pertanian Bogor

* Penulis korespondensi: e-mail: orusdiana@yahoo.com

${ }^{2}$ Mahasiswa Departemen Silvikultur, Fakultas Kehutanan Institut Pertanian Bogor
}

sehingga dapat memicu pemanasan global dan perubahan iklim bumi. Peningkatan emisi karbondioksida dipicu oleh penggunaan bahan bakar, deforestasi, dan perubahan tata guna lahan. Pada tahun 1850-1950 diperkirakan telah terjadi emisi karbondioksida sebesar 195 \pm 20 GtC dan pada tahun 1950-1980 diperkirakan terjadi emisi karbondioksida sebesar 117 $\pm 35 \mathrm{GtC}$, di mana satu Giga ton $(\mathrm{Gt})=$ satu milyar metrik ton .

PT Holcim Indonesia Tbk merupakan perusahaan yang bergerak di bidang pertambangan silika dan kapur untuk bahan baku pembuatan semen. Perusahaan ini telah melakukan kegiatan reklamasi pada areal pasca tambang sejak tahun 2005 dengan areal seluas 70 hektar yang berada di areal Holcim Educational Forest (HEF) Cibadak, Sukabumi. Kegiatan reklamasi diwajibkan kepada setiap perusahaan yang melakukan kegiatan pertambangan untuk merubah kembali areal yang telah di tambang menjadi hutan sesuai dengan Peraturan Pemerintah RI No. 78 Tahun 2010 tentang Reklamasi dan Pascatambang. Selama ini penelitian tentang potensi pendugaan karbon pada areal tersebut baru dilakukan pada jenis pinus (Pinus merkusii). Oleh karena itu, perlu diadakannya penelitian kembali tentang potensi simpanan karbon aktual pada tegakan tersebut untuk menghitung selisih jumlah karbon yang terkandung didalamnya setelah dilakukan penambangan. Penelitian ini bertujuan untuk menduga besarnya simpanan total biomassa dan karbon yang ada di tegakan pinus (Pinus merkusii) tahun tanam 2005 dan 2012 serta membandingkannya dengan pengukuran tahun sebelumnya pada areal revegetasi lahan pasca tambang PT Holcim Indonesia Tbk. 


\section{METODE PENELITIAN}

\section{Lokasi dan Waktu Penelitian}

Penelitian ini dilaksanakan pada tegakan pinus area revegetasi PT Holcim Tbk atau sekarang dikenal dengan Holcim Educational Forest (HEF) Sukabumi, Penelitian telah dilaksanakan pada bulan Mei - Juni 2016.

\section{Alat dan Bahan}

Alat yang digunakan dalam penelitian ini adalah peta penanaman PT Holcim Indonesia Tbk, haga hypsometer, galah, caliper digital, tambang, pita meter, pita ukur, patok, parang, cangkul, cat merah, tally sheet, alat tulis, kertas karton, plastik, trash bag, label, koran, oven, sasak, laptop, timbangan digital, dan kamera digital. Adapun bahan yang digunakan adalah koran, tegakan revegetasi, contoh tanah, serasah, tumbuhan bawah, dan data sekunder penelitian tahun 2015 (Oktavianto 2015)

\section{Prosedur Penelitian}

\section{Penentuan dan Pembuatan Plot di Lapang}

Petak yang digunakan untuk penelitian adalah areal bekas tambang silika yang terbagi atas beberapa bagian blok tanam. Pengukuran dilakukan pada dua kelas umur tanaman pinus (tanaman muda dan tanaman tua). Tegakan pinus tua merupakan tegakan dengan tahun tanam 2005 sedangkan untuk tegakan muda yaitu tegakan dengan tahun tanam 2012. Plot yang digunakan terdiri dari dua luasan yang berbeda yaitu 0.0567 ha untuk pinus tahun 2005 (Gambar 1A) dan 1.5 ha untuk pinus tahun 2012 (Gambar 1B). Selain pengukuran pohon, dibuat petak contoh berukuran $1 \mathrm{~m}$ x $1 \mathrm{~m}$ pada setiap kelas umur di kedua lokasi untuk menghitung biomassa serasah dan tumbuhan bawah.

\section{Inventarisasi Tegakan}

Inventarisasi tegakan dilakukan dengan mencatat lokasi, jenis pohon, dan kelas umur pohon pada setiap lembar tally sheet, tinggi total, dan Dbh (Diameter at Breast Height) untuk tegakan tua dan diameter pada tinggi $2 \mathrm{~cm}$ diatas tanah untuk tanaman pada tingkatan pancang dan semai. Khusus untuk tingkatan pancang dan semai pinus, tinggi total diukur hanya sebatas batang kayu tertinggi, sedangkan ekor tupai yang merupakan daun pinus yang tegak keatas tidak diukur.

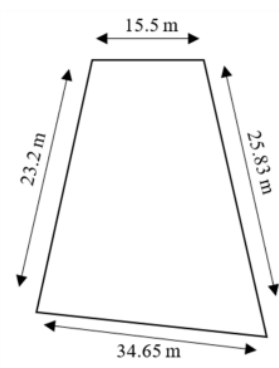

(A)

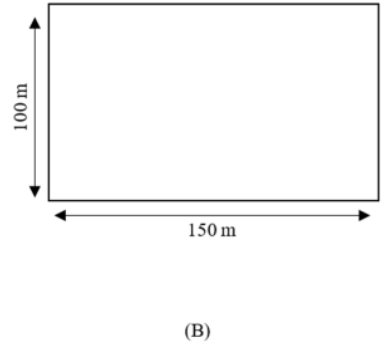

(B)
Gambar 1Plot contoh penelitian tegakan tahun tanam 2005 (A) dan 2012 (B)

\section{Pendugaan Biomassa Tegakan}

Pendugaan contoh biomassa tegakan dapat dihitung dengan mengambil data diameter setinggi dada $(1.3 \mathrm{~m}$ dari atas tanah untuk tanaman tua), diameter pada tinggi $2 \mathrm{~cm}$ di atas tanah (untuk tanaman muda atau pancang dan semai) dan tinggi pohon. Potensi biomassa tegakan dihitung dengan menggunakan persamaan alometrik.

\section{Pendugaan Biomassa Tumbuhan Bawah dan Serasah}

Pengukuran biomassa tumbuhan bawah dan serasah pada setiap petak penelitian dibentuk petak ukur berukuran $1 \mathrm{~m}$ x $1 \mathrm{~m}$ secara purposive sampling lalu dilakukan pengambilan contoh serasah dan tumbuhan bawah. Adapun seluruh serasah yang ada pada plot $1 \mathrm{~m}$ x $1 \mathrm{~m}$ dikumpulkan. Estimasi biomassa tumbuhan bawah dilakukan dengan mengambil bagian tanaman. Bagian tumbuhan bawah yang telah dipisahkan dan serasah yang telah dikumpulkan kemudian ditimbang sebanyak 200 gram untuk mendapatkan berat basah contohnya, apabila bagian tumbuhan tersebut memiliki berat kurang dari 200 gram maka seluruhnya dijadikan berat basah contoh. Setelah itu dilakukan pengovenan dengan suhu $80^{\circ} \mathrm{C}$ selama 2 x 24 jam (Hairiah et al 2011).

\section{Pengambilan Sampel Tanah}

Penentuan kandungan hara mineral yang terdapat di dalam tanah pengambilan contoh tanah terganggu dilakukan pada lapisan atas tanah kedalaman 0-20 cm. Pertimbangan menggunakan kedalaman tersebut karena unsur hara banyak terdapat pada horizon $\mathrm{O}$ dan $\mathrm{A}$ serta memudahkan untuk membandingkan dengan penelitanpenelitian tanah yang sudah dilakukan. Penentuan contoh tanah utuh dilakukan menggunakan ring tanah pada lima titik. Pengambilan tanah dilakukan secara purposive sampling yaitu dengan mengambil contoh tanah pada keempat ujung petak ukur dan tengah petak (Gambar 2).

\section{Analisis Data}

\section{Perhitungan Potensi Biomassa dan Stok Karbon Tegakan}

Model alometrik biomassa pohon yang dipilih adalah model alometrik dengan jenis tanaman dan tipe ekosistem yang sama serta berada dalam kisaran diameter yang ditentukan. Rumus yang digunakan untuk pendugaan biomassa adalah model alometrik untuk jenis Pinus merkusii di tipe ekosistem hutan tanaman dengan

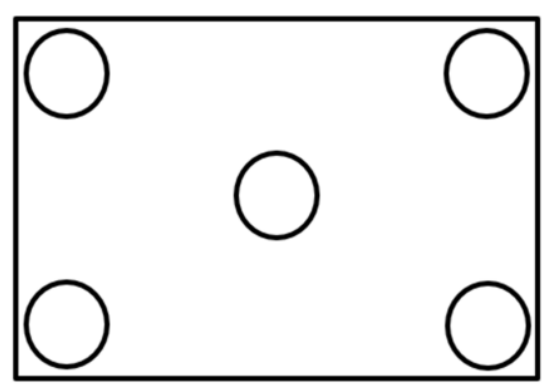

Gambar 2 Titik contoh pengambilan sampel tanah utuh dan terganggu 
kisaran diameter $0.4-44 \mathrm{~cm}$ (Siregar 2007 dalam Oktavianto 2015):

$$
\mathrm{BBA}=0.0936 \mathrm{D}^{2.4323}
$$

Keterangan :

$\mathrm{BBA}=$ Biomassa Bagian Atas

$\mathrm{D}=$ Diameter setinggi dada (1.3 $\mathrm{m}$ dari atas tanah untuk tanaman tua) dan Diameter pada tinggi 2 $\mathrm{cm}$ di atas tanah (untuk tanaman muda atau pancang dan semai)

Untuk perhitungan stok karbon pohon digunakan rumus konversi biomassa yang dikeluarkan IPCC 2006 dalam Oktavianto 2015 sebagai berikut:

$$
\mathrm{C}=0.47 \times \mathrm{B}
$$

Keterangan:

$\mathrm{C}=$ Karbon

$\mathrm{B}=$ Biomassa

\section{Perhitungan Potensi Biomassa Serasah dan Tumbuhan Bawah}

Perhitungan biomassa tumbuhan bawah dan serasah dilakukan dengan menghitung berat kering total. Rumus yang digunakan untuk menghitung kadar berat kering total menurut Hairiah et al. (2011) adalah sebagai berikut:

$$
\text { Total BK }=\frac{\text { BK sub contoh }(\mathrm{g})}{\text { BB sub contoh }(\mathrm{g})} \times \text { Total BB }(\mathrm{g})
$$

Keterangan :

$\mathrm{BB}=$ Berat Basah

$\mathrm{BK}=$ Berat Kering

\section{Perhitungan $\mathrm{CO}_{2}$-ekuivalen}

Perhitungan $\quad \mathrm{CO}_{2}$-ekuivalen menggunakan perbandingan massa atom relatif $\mathrm{C}$ (12) dengan massa molekul relatif $\mathrm{CO}_{2}$ (44). dirumuskan dengan (Kemenhut 2013 dalam Oktavianto 2015):

$$
\text { CO2 }- \text { ekuivalen }=\frac{44}{12} \times \text { stok karbon }
$$

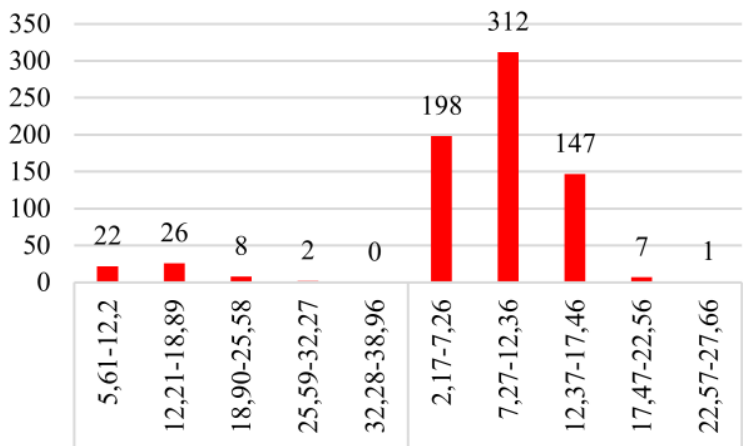

Interval Diameter (cm) 2005 Interval Diameter (cm) 2012

Gambar 3Sebaran diameter Pinus merkusii umur 11 tahun dan 4 tahun
Jumlah produksi oksigen dapat diduga dari sekuistrasi karbon berdasarkan berat atom (Ross dan Salisbury 1978 dalam Oktavianto 2015):

$$
\text { net } 02=\text { net } \mathrm{C} \times \frac{32}{12}
$$

Keterangan :

Net $\mathrm{O}_{2}=$ Pelepasan $\mathrm{O}_{2}$

Net $\mathrm{C}=$ Sekuestrrasi Karbon

\section{HASIL DAN PEMBAHASAN}

\section{Struktur horizontal}

Hasil inventarisasi tegakan umur 11 tahun ditemukan sebanyak 58 individu berada pada kisaran diameter 5.61-27.32 cm. Sedangkan hasil inventarisasi pada tegakan umur 4 tahun ditemukan sebanyak 665 individu berada pada kisaran diameter $2.17-23.28 \mathrm{~cm}$ (Gambar 3).

Tegakan pinus umur 11 tahun memilki nilai rentan sebesar $6.59 \mathrm{~cm}$. Nilai interval diameter dengan jumlah individu terbanyak yakni terdapat pada nilai interval $12.21-18.89 \mathrm{~cm}$ sebanyak 26 individu atau $44.83 \%$. Nilai interval diameter dengan jumlah individu terkecil yakni terdapat pada nilai interval $32.28-38.96 \mathrm{~cm}$ sebanyak 0 individu atau $0 \%$. Tegakan pinus umur 4 tahun memiliki nilai rentan sebesar $5.09 \mathrm{~cm}$. Untuk nilai interval diameter dengan jumlah individu terbanyak yakni terdapat pada nilai interval $7.27-12.36 \mathrm{~cm}$ sebanyak 312 individu atau $46.92 \%$. Sedangkan nilai interval diameter dengan jumlah individu terkecil yakni terdapat pada nilai interval 22.57-27.66 $\mathrm{cm}$ sebanyak 1 individu atau $0.15 \%$.

\section{Struktur vertical}

Hasil inventarisasi tegakan 11 tahun ditemukan sebanyak 58 individu berada pada kisaran tinggi $2.5-15$ m. Hasil inventarisasi pada tegakan umur 4 tahun ditemukan sebanyak 665 individu berada pada kisaran tinggi $0.5-7 \mathrm{~m}$ (Gambar 4).

Tegakan pinus umur 11 tahun memiliki nilai rentan sebesar $3.50 \mathrm{~m}$. Interval nilai dengan jumlah individu terbanyak yakni $2.5-6.0 \mathrm{~m}$ sebanyak 28 individu atau $48.28 \%$. Sedangkan untuk jumlah individu terkecil berada pada interval $16.9-19.4 \mathrm{~m}$ sebanyak 0 individu

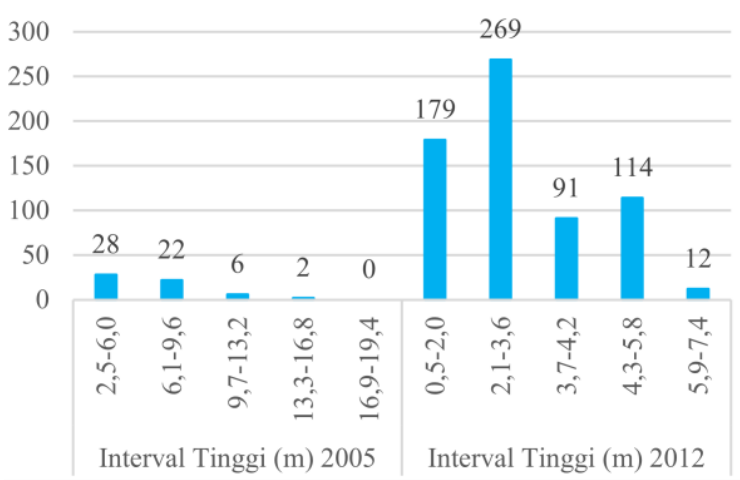

Gambar 4 Sebaran tinggi Pinus merkusii umur 11 tahun dan 4 tahun 
atau $0 \%$. Tegakan pinus umur 4 tahun memiliki nilai interval $1.50 \mathrm{~m}$. Interval nilai dengan jumlah individu terbanyak yakni $2.1-3.6 \mathrm{~m}$ sebanyak 269 individu atau $40.45 \%$. Jumlah individu terkecil berada pada interval 5.9-7.4 m sebanyak 12 individu atau $1.8 \%$.

\section{Biomassa dan Stok Karbon Tegakan}

Hasil penelitian yang dilakukan menunjukkan bahwa biomassa dan stok karbon pada tegakan pinus umur 11 tahun dan umur 4 tahun mengalami peningkatan 8.59-17.86 (ton/ha) untuk nilai biomassa dan 4.04-8.39 (ton/ha) untuk nilai stok karbon. Peningkatan juga terjadi pada nilai $\mathrm{CO}_{2}$-ekuivalen sebesar 14.81-0.78 (ton/ha) dan nilai pelepasan oksigen sebesar 10.77-22.38 (ton/ha) (Gambar 5).

Hasil pengukuran yang dilakukan pada tegakan umur 11 tahun untuk nilai biomassa diperoleh sebesar 75.31 (ton/ha) atau meningkat sebesar 17.86 (ton/ha) dari tahun pengukuran sebelumnya. Pada tegakan umur 4 tahun diperoleh nilai biomassa sebesar 12.72 (ton/ha) atau meningkat sebesar 8.59 (ton/ha) dari tahun pengukuran sebelumnya. Nilai stok karbon pada tegakan umur 11 tahun dan umur 4 tahun diperoleh sebesar 35.39 (ton/ha) dan 5.98 (ton/ha) dengan perubahan berturutturut sebesar 8.39 (ton/ha) dan 4.04 (ton/ha) dari tahun pengukuran sebelumnya. Nilai $\mathrm{CO}_{2-}$ ekuivalen dan pelepasan oksigen pada tegakan umur 11 tahun diperoleh sebesar 129.79 (ton/ha) dan 94.39 (ton/ha) atau meningkat sebesar 30.78 (ton/ha) dan 22.38 (ton/ha) dari pengukuran tahun sebelumnya. Nilai $\mathrm{CO}_{2}$-ekuivalen dan pelepasan oksigen pada tegakan umur 4 tahun diperoleh sebesar 21.93 (ton/ha) dan 15.95 (ton/ha) atau meningkat sebesar 14.81 (ton/ha) dan 10.77 (ton/ha).

\section{Biomassa Serasah Dan Tumbuhan Bawah}

Hasil perhitungan biomassa serasah dan tumbuhan bawah pada tegakan umur 11 tahun dan umur 4 tahun diperoleh biomassa tumbuhan bawah dengan peningkatan berkisar antara 0.2279-0.6852 (ton/ha). Namun biomassa serasah pada tegakan umur 11 tahun mengalami peningkatan sebesar 0.7719 (ton/ha) dan

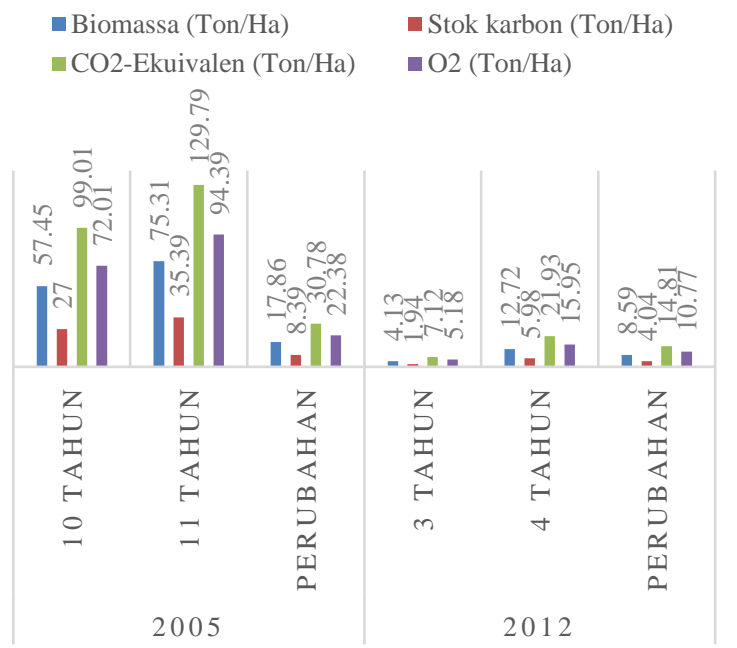

Gambar 5 Hasil pendugaan biomassa, perhitungan stok karbon, CO2-ekuivalen dan pelepasan oksigen tegakan umur 4 tahun mengalami penurunan sebesar 0.4808 (ton/ha) (Gambar 6).

Hasil pengukuran yang dilakukan pada tegakan umur 11 tahun untuk nilai biomassa tumbuhan bawah dan serasah diperoleh sebesar 2.0159 (ton/ha) dan 2.5019 (ton/ha) atau meningkat sebesar 0.2279 (ton/ha) dan 0.7719 (ton/ha) dari tahun pengukuran sebelumnya. Tegakan umur 4 tahun untuk nilai biomassa tumbuhan bawah dan serasah diperoleh sebesar 3.173 (ton/ha) dan 4.3424 (ton/ha) atau meningkat sebesar 0.6852 (ton/ha) untuk biomassa tumbuhan bawah dan menurun sebesar 0.4808 (ton/ha) untuk biomassa serasah dari tahun pengukuran sebelumnya.

\section{Sifat Fisik Tanah}

Pengamatan yang dilakukan pada sifat fisik tanah dengan menggunakan contoh tanah utuh dengan menggunakan metode ring sample diperoleh nilai bulk density (BD) pada tegakan umur 11 tahun dan 4 tahun berkisar antara $1.101-1.168\left(\mathrm{~g} / \mathrm{cm}^{3}\right)$. Nilai porositas pada tegakan umur 11 tahun dan 4 tahun berkisar antara $58.451-55.940 \%$. Nilai air tersedia pada tegakan umur 11 tahun dan 4 tahun berkisar antara 13.196-15.401\% (Gambar 7).

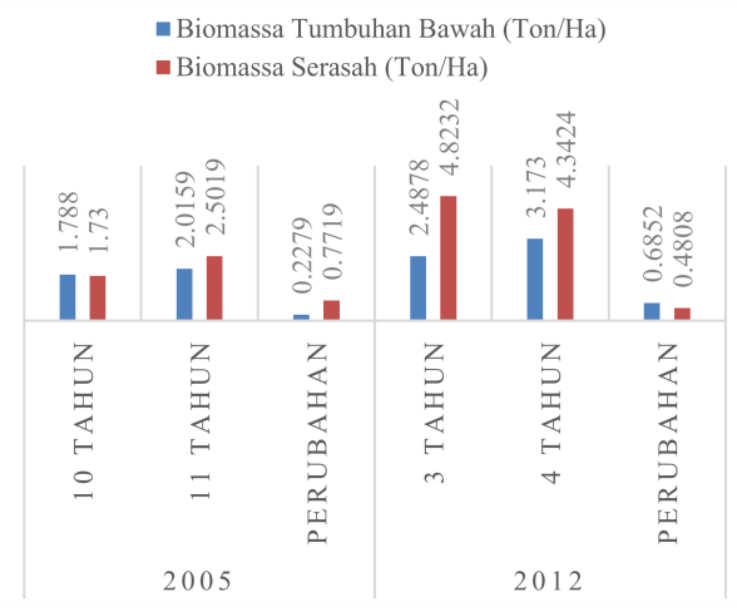

Gambar 6 Grafik hasil pendugaan biomassa tumbuhan bawah dan serasah

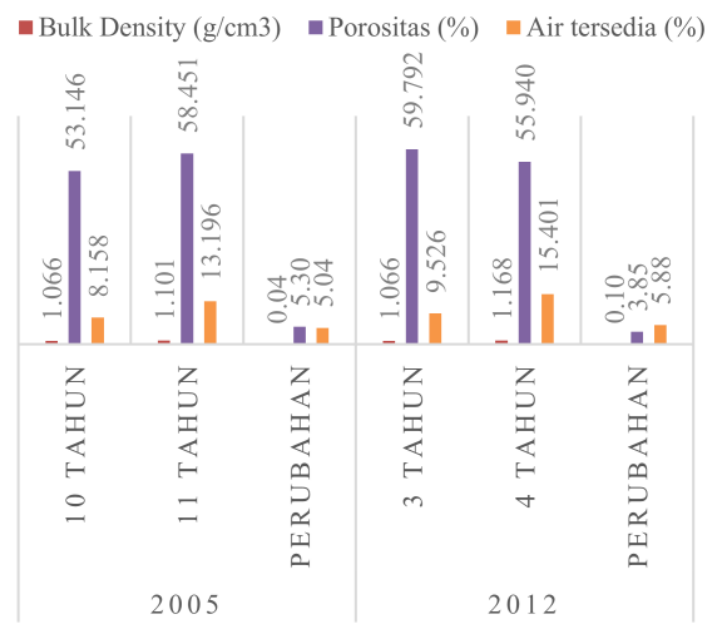

Gambar 7 Grafik perbandingan hasil BD. porositas. dan air tersedia 
Hasil pengukuran yang dilakukan pada tegakan umur 11 tahun untuk nilai BD diperoleh sebesar 1.101 $\left(\mathrm{g} / \mathrm{cm}^{3}\right)$ atau meningkat sebesar $0.04\left(\mathrm{~g} / \mathrm{cm}^{3}\right)$ dari tahun pengukuran sebelumnya. Tegakan umur 4 tahun untuk nilai BD diperoleh sebesar $1.168\left(\mathrm{~g} / \mathrm{cm}^{3}\right)$ atau meningkat sebesar $0.10\left(\mathrm{~g} / \mathrm{cm}^{3}\right)$ dari tahun pengukuran sebelumnya. Nilai pororsitas pada tegakan umur 11 tahun diperoleh sebesar $58.451 \%$ atau meningkat dari pengukuran tahun sebelumnya sebesar 5.30\%. Tegakan umur 4 tahun untuk nilai porositas sebesar $55.940 \%$ atau menurun dari tahun pengukuran sebelumnya sebesar $3.85 \%$. Nilai air tersedia pada tegakan umur 11 tahun diperoleh sebesar $13.196 \%$ atau meningkat sebesar $5.04 \%$ dari pengukuran tahun sebelumnya. Nilai air tersedia pada tegakan umur 4 tahun diperoleh sebesar $15.401 \%$ atau meningkat sebesar $5.88 \%$

\section{Sifat Kimia Tanah}

Pengamatan yang dilakukan pada sifat kimia tanah dengan menggunakan contoh tanah terganggu dengan menggunakan metode komposit diperoleh data sebagai berikut: nilai C-organik pada tegakan umur 11 tahun dan 4 tahun berkisar antara $0.41-0.80 \%$. Nilai $\mathrm{N}$ total pada tegakan umur 11 tahun dan 4 tahun berkisar antara $0.09-0.12 \%$. Nilai $\mathrm{C} / \mathrm{N}$ ratio pada tegakan umur 11 tahun dan 4 tahun berkisar antara 4.56-6.67\% (Gambar 8).

Hasil pengukuran yang dilakukan pada tegakan umur 11 tahun untuk nilai C-organik diperoleh sebesar $0.80 \%$ atau menurun sebesar $1.56 \%$ dari tahun pengukuran sebelumnya. Tegakan umur 4 tahun untuk nilai C-organik diperoleh sebesar $0.41 \%$ atau menurun sebesar $0.02 \%$ dari tahun pengukuran sebelumnya. Nilai $\mathrm{N}$ total pada tegakan umur 11 tahun dan 4 tahun diperoleh sebesar $0.12 \%$ dan $0.09 \%$ dengan perubahan berturutturut sebesar $0.03 \%$ atau menurun dan $0.05 \%$ atau meningkat dari tahun pengukuran sebelumnya. Nilai $\mathrm{C} / \mathrm{N}$ ratio pada tegakan umur 11 tahun diperoleh sebesar 6.67 atau menurun sebesar 9.07 dari pengukuran tahun sebelumnya. Nilai $\mathrm{C} / \mathrm{N}$ ratio pada tegakan umur 4 tahun diperoleh sebesar 4.56 atau menurun sebesar 6.19.

\section{Struktur Tegakan}

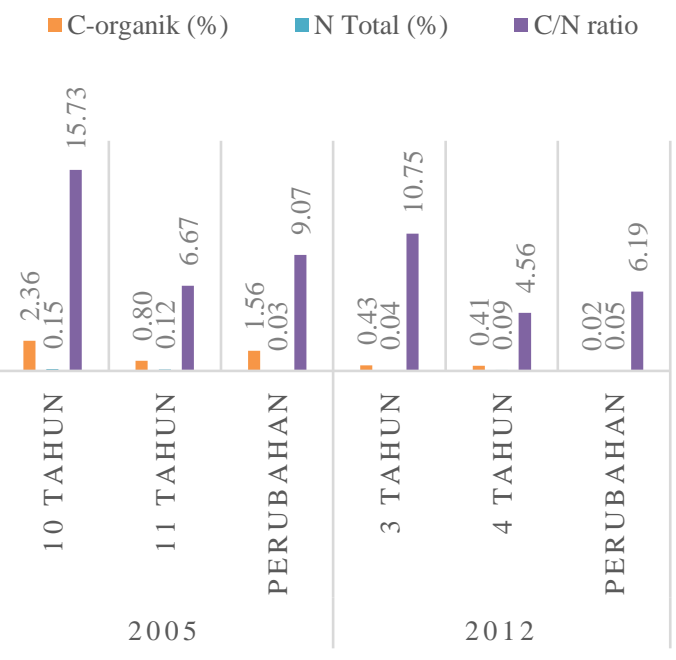

Gambar 8 Grafik perbandingan hasil C-organik, N Total, dan C/N Ratio
Struktur horizontal pada tegakan pinus umur 11 tahun dan 4 tahun relatif stabil dan menyebar pada setiap kelas diameter. Hasil pengukuran struktur horizontal pada kedua tegakan menunjukkan populasi tegakan dengan diameter kecil memiliki angka yang lebih besar dalam hal jumlah sehingga menyerupai pola penyebaran diameter dari hutan alam secara umum. Hal ini dikemukakan oleh Abdurachman (2008), kejadian umum pada hutan alam dimana kelas diameter kecil mendominasi areal hutan dan mengalami penurunan pada pada kelas diameter yang besar. Kondisi tempat tumbuh yang merupakan areal bekas tambang silika menyebabkan kondisi setiap individu tanaman berbeda dalam hal perkembangan dan pertumbuhan sehingga menyebabkan terjadinya perbedaan diameter antar individu yang memiliki jenis dan umur tanam yang sama. Hal ini sesuai dengan pendapat Smith (1962) dalam Abdurachman (2008), struktur suatu tegakan hutan sangat dipengaruhi oleh faktor-faktor yang berpengaruh terhadap pertumbuhan pohon penyusunnya seperti faktor biotik dan genetik yang dimiliki setiap jenis pohon dan faktor lingkungannya.

Nilai diameter akan meningkat seiring dengan berjalannya waktu pada fase pertumbuhan tanaman dan akan berhenti atau stagnan pada fase pertumbuhan mencapai optimal atau puncak pertumbuhan. Nilai pertambahan diameter tahunan pada tegakan pinus umur 11 tahun dan 4 tahun berturut-turut sebesar 1.29 (cm/tahun) dan 2.41 (cm/tahun). Diameter tahunan tegakan umur 11 tahun lebih kecil jika dibandingkan dengan penelitian (Siregar, Sidabutar, dan Siregar 2013), pada tegakan pinus umur 10 tahun yang memiliki riap diameter sebesar 1.841 (cm/tahun). Nilai diameter tahunan untuk tegakan pinus umur 4 tahun lebih besar jika dibandingkan dengan penelitian Harmoko (2004) dalam Siregar, Sidabutar, dan Siregar (2013) pada tegakan pinus umur 4 tahun yang memiliki riap diameter sebesar 1.9 (cm/tahun). Tegakan pinus tahun tanam 2005 atau umur 11 tahun perawatan atau pengelolaan khusus hanya dilakukan satu tahun sekali oleh pihak HEF sehingga memiliki nilai riap diameter yang kecil. Pada tegakan pinus tahun tanam 2012 dilakukan perawatan (pemupukan bokasi $10 \mathrm{~kg}$ per tanaman dan NPK mutiara 100 gr per tanaman) dan pengelolaan khusus logam berat (low lime dan forlima) dan penanaman legume cover crop setiap tiga bulan sehingga memiliki nilai riap diameter yg besar.

Pertumbuhan tinggi yang sangat kecil disebabkan ruang tumbuh atau areal tegakan umur 11 tahun dan 4 tahun merupakan tanah urugan sedalam kurang lebih satu meter yang dibawahnya terdapat sisa batuan bekas tambang. Tanah di sekeliling areal pertumbuhan merupakan tanah mineral yang telah mengeras dan memerlukan alat berat untuk pengelolaannya. Hal tersebut dapat menjadi faktor pembatas akar untuk berkembang optimal menuju dasar tanah dan hanya dimungkinkan untuk berkembang secara horizontal. Menurut Utomo dan Islami (1995), faktor yang mempengaruhi pertumbuhan dan sistem perakaran adalah faktor dalam (hereditas) dan faktor luar (lingkungan). Faktor lingkungan yang mempengaruhi sistem perakaran adalah kelembaban tanah, suhu tanah, kesuburan tanah, kemasaman tanah $(\mathrm{pH})$, aerasi tanah, 
hambatan mekanis tanah, kompetisi, dan interaksi perakaran. Hardjowigeno (2010) menyebutkan bahwa kedalaman efektif mempengaruhi pertumbuhan dan pengembangan akar, drainase, dan ciri fisik tanah. Tanah dengan kedalaman efektif dangkal menyebabkan terhambatnya perkembangan akar tanaman dan tanah dengan kedalaman efektif dalam akan mempunyai aerasi dan drainase yang baik, serta mampu menyokong perkembangan akar dan tanaman dengan baik.

\section{Biomassa dan Stok Karbon Tegakan}

Pengukuran biomassa, stok karbon, $\mathrm{CO}_{2}$-ekuivalen, dan pelepasan $\mathrm{O}_{2}$ pada tegakan umur 11 tahun dan 4 tahun mengalami peningkatan dari tahun sebelumnya. Hasil pengukuran yang dilakukan pada tahun pengukuran 2016 tentang nilai biomassa, stok karbon, $\mathrm{CO}_{2}$-ekuivalen, dan pelepasan $\mathrm{O}_{2}$ lebih tinggi dari pengukuran tahun sebelumnya diduga karena adanya pertambahan riap diameter dan riap tinggi tahunan pada areal atau plot tersebut. Hal ini sesuai dengan pernyataan Siregar (2012), biomassa pohon meningkat seiring dengan meningkatnya diameter batang.

Hasil pengukuran yang dilakukan pada tegakan umur 11 tahun untuk nilai biomassa dan stok karbon diperoleh sebesar 75.31 (ton/ha) dan 35.39 (ton/ha). Jika hasil penelitian dibandingkan dengan penelitian Siregar (2007) pada tegakan pinus umur 11 tahun dengan kerapatan $1250 \mathrm{~N} /$ ha memiliki nilai biomassa sebesar 128 (ton/ha) dan nilai stok karbon sebesar 64.50 (ton/ha) atau jauh lebih besar dari hasil penelitian yang dilakukan. Tegakan umur 4 tahun untuk nilai biomassa dan stok karbon diperoleh sebesar 12.72 (ton/ha) dan 5.98 (ton/ha). Jika hasil penelitian dibandingkan dengan penelitian Siregar (2007), pada tegakan pinus umur 4 tahun dengan kerapatan $1250 \mathrm{~N} / \mathrm{ha}$ memiliki nilai biomassa sebesar 22.35 (ton/ha) dan nilai stok karbon sebesar 11.18 (ton/ha) atau jauh lebih besar dari penelitian yang dilakukan. Kondisi tersebut dapat disebabkan oleh perbedaan kualitas tempat tumbuh, kerapatan tegakan, dan ukuran diameter yang berbeda pada lokasi penelitian. Hal ini sesuai dengan pendapat Chanan (2012), yang menyatakan bahwa perbedaan pada biomassa dan karbon pada tegakan tersebut lebih cendrung dipengaruhi oleh kerapatan tegakan, umur tegakan, dan kualitas tempat tumbuh tegakan.

\section{Biomassa Serasah dan Tumbuhan Bawah}

Hasil pengukuran yang dilakukan pada tegakan umur 11 tahun untuk nilai biomassa tumbuhan bawah dan serasah diperoleh sebesar 2.0159 (ton/ha) dan 2.5019 (ton/ha) atau meningkat sebesar 0.2279 (ton/ha) dan 0.7719 (ton/ha) dari tahun pengukuran sebelumnya. Tegakan umur 4 tahun untuk nilai biomassa tumbuhan bawah dan serasah diperoleh sebesar 3.173 (ton/ha) dan 4.3424 (ton/ha) atau meningkat sebesar 0.6852 (ton/ha) untuk biomassa tumbuhan bawah dan menurun sebesar 0.4808 (ton/ha) untuk biomassa serasah dari tahun pengukuran sebelumnya.

Kondisi tersebut diduga karena meningkatnya umur tegakan, intensitas hujan yang tinggi, penyiangan yang belum dilakukan, berat kering tanaman dan kondisi kadar air, keterbukaan tajuk dan kondisi iklim, sehingga jatuhan serasah dan kondisi tumbuhan bawah melimpah pada petak contoh pengambilan. Menurut Rusdiana dan Lubis (2012), ketika berat kering (BK) tumbuhan bawah dan serasah semakin besar, maka kadar air (KA) akan semakin kecil sehingga biomassa atau karbon tersimpan akan semakin besar. Begitu sebaliknya, jika berat kering (BK) tumbuhan bawah dan serasah semakin kecil, maka kadar air (KA) akan semakin besar sehingga biomassa atau karbon tersimpan yang dihasilkan akan semakin kecil.

\section{Sifat Fisik Tanah}

Hasil pengukuran tahun 2015 untuk tegakan umur 11 tahun memiliki nilai lebih besar dalam nilai bulk density, porositas, dan air tersedia. Pengukuran pada tegakan umur 4 tahun lebih besar ketimbang pengukuran tahun 2015 dalam nilai bulkdensity dan air tersedia sedangkan untuk nilai porositas mengalami penurunan. Hal ini diduga karena terjadi pemadatan akibat tidak adanya pengolahan tanah, lahan yang terbuka, aktivitas manusia karena petak tersbut adalah areal berfoto, dan berkurangnya bahan organik tanah.

Blake dan Hartage (1986) dalam Andayani (2009), menyatakan bahwa nilai bulk density sangat sensitif terhadap pengolahan tanah. Pengolahan tanah yang baik dapat menurunkan bulk density dan menghancurkan struktur, tetapi pengolahan tanah yang buruk dapat menaikkan bulk density. Menurut Buckman dan Brady (1992) dalam Silamon (2004), bobot isi tanah juga dipengaruhi oleh kandungan bahan organik tanah. Semakin tinggi bahan organik tanah maka akan semakin rendah bobot isi tanah tersebut, hal ini dikarenakan adanya pengaruh aktivitas organisme tanah. Serasah yang terdekomposisi menjadi bahan organik akan menjadi nutrisi bagi organisme tanah sehingga akan mengundang binatang tanah untuk tinggal dan beraktivitas disekitar lokasi tersebut yang menyebabkan tanah menjadi lebih sarang. Semakin banyak serasah yang terdekomposisi akan menyebabkan tanah semakin sarang dan menurunkan nilai bulk density. Sedangkan menurut Purwanto dan Ginting (1994) dalam Hayuningtyas (2006), menurunnya kandungan bahan organik tanah umumnya akan meningkatkan bobot isi tanah. Menurut Hardjowigeno (2010), porositas tanah dipengaruhi kandungan bahan organik. struktur tanah, dan tekstur tanah. Porositas tanah tinggi kalau bahan organik tinggi.

\section{Sifat Kimia Tanah}

Hasil pengukuran pada tegakan umur 11 tahun dan 4 tahun untuk nilai C-organik termasuk sangat rendah, nilai $\mathrm{N}$ total rendah hingga sangat rendah, dan $\mathrm{C} / \mathrm{N}$ ratio rendah hingga sangat rendah (Pusat Penelitian Tanah 1983 dalam Hardjowigeno 2010). Peningkatan atau penurunan yang terjadi pada nilai $\mathrm{C}$-organik, $\mathrm{N}$ total, dan $\mathrm{C} / \mathrm{N}$ ratio dikarenakan ada atau tidaknya suplai bahan organik, radiasi matahari, dan pencucian hara karena lahan yang relatif miring. Hal ini sesuai dengan pendapat Sanchez (1992) dalam Hayuningtyas (2006), kehilangan karbon dan nitrogen dari tanah disebabkan oleh penyerapan (uptake) oleh akar tanaman, penguapan, pencucian, denitrifikasi, dan pengikisan. 
Selain itu sifat fisik tanah yang sarang disebabkan oleh tekstur tanah ringan (dominasi pasir) sehingga mempercepat terjadinya oksidasi, daya menahan airnya rendah, dan karena berukuran besar meciptakan ruangan yang besar, sehingga air berperlokasi cepat. Akibatnya bahan organik atau unsur hara lebih mudah dan lebih cepat tercuci bersama aliran air permukaan. Menurut Hanafiah (2005), hilangnya $\mathrm{N}$ dari tanah juga disebabkan penggunaan untuk metabolisme tanaman dan mikrobia selain itu juga $\mathrm{N}$ dalam bentuk nitrat sangat mudah tercuci oleh air hujan. Keberadaan bahan organik tanah ini sangat penting dalam penentuan kesuburan suatu tanah. Bahan organik menyimpan unsur-unsur hara seperti $\mathrm{N}$ total. hara essensial. mineral tanah dan sebagainya. Besarnya nilai $\mathrm{pH}$, kandungan $\mathrm{C}$-Organik dan kation basa $\left(\mathrm{Ca}^{2+}, \mathrm{Mg}^{2+}, \mathrm{K}^{+}\right.$dan $\left.\mathrm{Na}^{+}\right)$sangat erat kaitannya dengan KTK tanah. KTK merupakan sifat kimia tanah yang sangat erat hubungannya dengan kesuburan tanah yakni sebanding dalam kemampuan menjerap dan menyediakan unsur hara tanaman (Hardjowigeno 2010).

\section{SIMPULAN DAN SARAN}

\section{Simpulan}

Nilai hasil pendugaan simpanan biomassa dan stok karbon pada tegakan umur 11 tahun diperoleh hasil sebesar 75.31 (ton/ha) dan 35.39 (ton/ha). Sedangkan tegakan umur 4 tahun untuk nilai biomassa dan stok karbon diperoleh sebesar 12.72 (ton/ha) dan 5.98 (ton/ha). Hasil ini menunjukkan adanya peningkatan pada tegakan tersebut, jika dibandingkan dengan penelitian tahun 2015.

Hasil pengukuran yang tegakan umur 11 tahun untuk nilai biomassa tumbuhan bawah dan serasah diperoleh sebesar 2.0159 (ton/ha) dan 2.5019 (ton/ha) atau meningkat sebesar 0.2279 (ton/ha) dan 0.7719 (ton/ha) dari tahun pengukuran sebelumnya. Sedangkan tegakan umur 4 tahun untuk nilai biomassa tumbuhan bawah dan serasah diperoleh sebesar 3.173 (ton/ha) dan 4.3424 (ton/ha) atau meningkat sebesar 0.6852 (ton/ha) untuk biomassa tumbuhan bawah dan menurun sebesar 0.4808 (ton/ha) untuk biomassa serasah dari tahun pengukuran sebelumnya.

Saran
Perlu adanya penelitian lanjutan dengan
menggunakan metode destruktif untuk mengetahui
persamaan yang tepat untuk menduga karbon pada
tegakan paska tambang, penelitian lanjutan mengenai
pencucian hara pada areal tersebut, dan penambahan

bahan organik sebagai asupan nutrisi bagi tegakan dan untuk peningkatan kualitas tempat tumbuh.

\section{DAFTAR PUSTAKA}

Abdurachman. 2008. Struktur tegakan pada hutan alam bekas tebangan. Info Teknis Dipterokarpa. 2(1):59-66.

Andayani WS. 2009. Laju infiltrasi tanah pada tegakan jati (Tectona grandis linn F) di BKPH Subah KPH Kendal Unit I Jawa Tengah. [skripsi]. Bogor (ID): Departemen silvikultur, Fakultas Kehutanan IPB.

Hairiah K, Ekadinata A, Sari RR, Rahayu S. 2011. Pengukuran Cadangan Karbon: dari Tingkat Lahan ke Bentang Lahan. Bogor (ID): World Agroforestry Centre, ICRAF Southeast Asia.

Hanafiah KA. 2005. Dasar-Dasar Ilmu Tanah. Jakarta (ID): PT Raja Grafindo Persada.

Hardjowigeno S. 2010. Ilmu Tanah. Jakarta (ID): Akademika Pressindo.

Hayuningtyas ADH. 2006. Perubahan sifat fisik dan kimia tanah dalam pelaksanaan sistem Tebang Pilih Tanam Jalur (TPTJ) di HPHTI PT. Sari Bumi Kusuma Unit S, Seruyan, Kalimantan Tengah. [skripsi]. Bogor (ID): Jurusan Budidaya Hutan, Fakultas Kehutanan IPB.

Oktavianto B. 2015. Pendugaan biomassa dan karbon atas tanah pada tegakan pinus di lahan paska tambang silika Holcim Educational Forest. [tesis]. Bogor (ID): Fakultas Kehutanan IPB.

Rusdiana O dan Lubis RS. 2012. Pendugaan korelasi antara karakteristik tanah terhadap cadangan karbon (Carbon Stock) pada Hutan Sekunder. Jurnal Silvikultur Tropika. 3(1):14-21.

Silamon RF. 2004. Analisa laju infiltrasi pada perbedaan kerapatan tegakan hutan pinus (Pinus merkusii). Blok Cimenyan, Hutan Pendidikan Gunung Walat, Sukabumi-Jawa Barat. [skripsi]. Bogor (ID): Departemen Manajemen Hutan, Fakultas Kehutanan IPB.

Siregar CA. 2007. Pendugaan biomasa pada hutan tanaman pinus (Pinus merkusii Jungh. et de Vriese) dan konservasi karbon tanah di Cianten, Jawa Barat). Jurnal Penelitian Hutan dan Konservasi Alam. 4(3):251-266.

Siregar UJ, Sidabutar J, Siregar CA. 2013. Perubahan karakteristik kimia tanah pada model reklamasi lahan bekas tambang PT. Antam UBPE Pongkor. Jurnal Silvikultur Tropika. 4(3):141-149.

Utomo WH dan Islami T. 1995. Hubungan Tanah. Air Dan Tanaman. Semarang (ID): IKIP Semarang Press. 